\title{
Understandings of Mentoring within Initial Teacher Education School Placement Contexts: a Scottish perspective
}

Dr Lorele Mackie

Faculty of Social Sciences, University of Stirling, Stirling, Scotland, UK

RG Bomont Building

University of Stirling

Stirling

FK9 4LA

lorele.mackie@stir.ac.uk

This is an Accepted Manuscript of an article published by Taylor \& Francis Group in Professional Development in Education on 15 Nov 2017, available online: http://www.tandfonline.com/10.1080/19415257.2017.1398179 


\title{
Understandings of Mentoring within Initial Teacher Education School Placement Contexts: a Scottish perspective
}

\begin{abstract}
Within the context of Scottish Initial Teacher Education, this qualitative study critically addresses mentor and mentee understandings of mentoring primary education student teachers. It introduces a Scottish perspective to the international body of literature on student teacher mentoring, and contributes new understandings of mentoring by addressing the role of mentees as well as those of the mentor. An instrumental, collective case study research design was employed with semi-structured interviews of six class teacher mentors and their student teachers conducted to ascertain understandings of the mentoring process. Findings indicate that participants understood mentoring as a multidimensional process designed to support the professional learning of student teachers. The key mentoring relationship is between class teacher mentor and mentee, and essential in developing mentee teaching capacity. Analysis of responses suggests an understanding of mentoring as involving both personal and professional dimensions. The data reveals the complex nature of the mentoring process in terms of the multitude of potential interpretations of these two dimensions and of the ways in which they overlap. It is recommended that all teacher education programmes and associated placement schools consider the provision of effective mentor and mentee education to improve the quality and consistency of mentoring for student teachers.
\end{abstract}

Keywords: mentoring; Initial Teacher Education; mentor education; mentee education

\section{Introduction}

The context of a 'knowledge society', with lifelong learning as a requisite capacity, suggests that the processes of learning and teaching are critical (Forde, McMahon, McPhee and Patrick 2006). This requires changes to the way teaching is conceptualised in that broader, more complex knowledge, skill and competence bases are essential. This, in turn, has implications for the nature and quality of the future generation of teachers in terms of the attributes necessary to develop appropriate capacities in learners, and the mentoring practices required to promote such attributes. In order to foster effective mentoring in both university and school contexts, understanding its complexities is vital.

Within the context of Initial Teacher Education (ITE), this article references an empirical research project aimed at investigating mentor and mentee understandings of mentoring primary education student teachers within Scottish school placement contexts. It introduces a Scottish perspective to the international body of literature on student teacher mentoring and contributes understandings of mentoring by addressing the role of mentees as well as those of the mentor, thereby filling a gap in current literature (Ambrosetti 2010). It emphasises the need for quality and consistent programmes of mentor and mentee education within ITE settings. Current Scottish education policy is used to frame and exemplify points made alongside those from international literature to inform discussions.

\section{Mentoring Complexity in Teacher Education}

Mentoring beginner teachers is a complex endeavour (Harrison, Lawson and Wortley 2005; Heirdsfield, Walker, Walsh and Wilss 2008) involving the mentor/mentee relationship, associated roles, needs and aims, which are influenced by external and internal contexts (Ambrosetti 2012). The term mentoring in itself can mean many different things (Ambrosetti and Dekkers 2010). Coaching and mentoring are often used interchangeably but the distinction is an important one (Kemmis, Heikkinen, Fransson, Aspfors and Edwards-Groves 2014). For example, coaching may be 
viewed as a process that fosters progression in the performance of teams and individuals focusing on particular skills (Arnot and Sparrow 2004). Mentoring connotes a more experienced colleague supporting, challenging and facilitating the learning of another (Pollard 2005; Carnell, MacDonald and Askew 2006). Arguably, coaching is an aspect of mentoring, and mentoring can involve coaching (Cordingley, Bell and Temperley 2005; Carnell et al. 2006).

The complex nature of mentoring leads to the construction of multiple understandings. As such, there is no one 'recipe for success' (Harrison et al. 2005, p 425 ) and so a number of mentoring models exist. It may also take on different meanings and forms depending on cultural and structural aspects of learning environments (Carnell et al. 2006; Kemmis et al. 2014). For instance, mentoring within a quality assurance environment may be restricted to supervision of skills (Rix and Gold 2000). This can become prescriptive, directive and normative conduct (ibid.) that prevents dialogue because it is based on accepted traditions and separation of groups (Sachs 2000) such as expert and novice teachers. In contrast, reflective of constructivist theories, more collaborative school cultures adopt less directive, more educative strategies in their emphasis on developing autonomy and self-regulatory capacities (Iancu and Oplatka 2014).

Yeomans and Sampson's (1994) well-documented model of structural, supportive and professional dimensions of mentoring is a helpful framework for understanding mentoring in conjunction with others such as Kwan and Lopez-Real's (2005) model of pragmatic, managerial and interpersonal elements derived from research in Hong Kong, and the relational, developmental and contextual aspects employed by Ambrosetti, Knight and Dekker (2014) in Australia. These models build on the work of Yeomans and Sampson in different ways. Kwan and Lopez-Real's (2005) model references significant mentor roles and is reflective of the professional and supportive dimensions identified by Yeomans and Sampson. Ambrosetti et al. (2014) adopt a specific focus on mentoring relationships and influential contexts beyond school settings. This study and others (for example, Kwan and Lopez-Real, 2005; Dewhurst and Mcmurty, 2006; Rajuan et al., 2007; Laker et al., 2008; Jones, 2009; Ambrosetti, 2010; Achinstein and Davis, 2014) focus on the mentor within the process of mentoring. However, Ambrosetti and Dekkers (2010) note a limited amount of literature on the mentee role in a mentoring relationship. Key roles identified are working with a mentor to foster appropriate knowledge and skills, teaching lessons, observing mentors, having professional dialogue, carrying out requisite tasks, identifying targets and engaging in reflective practice (ibid.).

Yeomans and Sampson's structural dimension is described as focusing on the mentee as a person, as opposed to a student teacher, thereby fostering a humanistic approach. It refers to activities promoting a school environment where mentees experience success in their professional learning (ibid.). The professional dimension emphasises mentee professional learning in the practicalities of learning to teach and the mentor roles involved in this process (ibid.). The supportive dimension focuses on interpersonal aspects and entails a mentor adopting roles such as host, friend and counsellor (ibid.).

Mentor and mentee roles and relationships are further explored within mentoring models in terms of procedure, power and personal elements (Rippon and Martin 2003). Procedural relationships focus on technical aspects of teaching and do not account for mentee needs or capabilities (Harrison et al. 2005). Those based on power centre on the mentor/mentee relationship as 'apprenticeship' where support may be deficient and compliance expected (ibid.). Personal relationships emphasise 
collaboration between mentor and mentee with constructive dialogue as a key component in developing understanding (ibid.). A continuum of mentoring styles may be derived from these relationships from directive to non-directive, namely those where mentors give information and instruct to those that encourage mentees to be reflective, autonomous practitioners (ibid.). These styles may alter in emphasis as mentees progress through different stages of learning to teach (Maynard and Furlong 1993; Pollard 2005). Such continuums and models should be viewed as recursive and cumulative (Furlong, Barton, Miles, Whiting and Whitty 2000) to reflect the developmental concerns of mentees, highlighting mentor judgements about individual mentee requirements (Strong and Baron 2004), while recognising that these may contradict mentee desires (Pollard 2005). These judgments are mediated by an appreciation that student teachers develop at different rates and often need to revisit some aspects of learning in more depth (Furlong et al., 2000).

While the focus of mentoring tends to be on mentees, mentors may also benefit in terms of their professional learning (Hargreaves and Fullan 2000; Heirdsfield et al. 2008), for example, in terms of currency of knowledge, greater comprehension of their own practice, capacity regarding variety of mentoring strategies, increased self-esteem (Carnell et al. 2006), reflective practice and professional dialogue (Lopez-Real and Kwan 2005). As members of a professional learning community mentors may also learn to become more effective by reflecting critically on experiences through interactions with other mentors (Feiman-Nemser and Parker 1992).

\section{Scottish Context}

In Scotland all prospective teachers must undertake either a four-year undergraduate or one-year postgraduate qualification within a university provider (GTCS 2012). Students are required to complete modules within university as well as school placement experiences in order to meet the General Teaching Council of Scotland's (GTCS) competencies for the Standard for Initial Teacher Education (SITE) (ibid.). On programme completion, in order to obtain full GTCS registration, all students undertake an induction year to evidence competence against the Standard for Full Registration (SFR) (ibid.). This process is the only route to obtaining full GTCS registration. Other countries, such as England and the USA, have more available pathways including school-based teacher training (UKK 2014).

Mentoring within Scottish ITE has been reported as variable in quality for a number of years (Deloitte and Touche 2001; HMIe 2005; Scottish Executive 2005; Scottish Government 2011; Education Scotland 2015). As such, the latest review of teacher education recommends that mentoring be addressed at national and local levels to ensure quality provision (Scottish Government 2011), and that mentors should be chosen for their knowledge, understanding and skills in mentoring and requisite assessments. It attests that all teachers should see themselves as responsible for teacher education and be provided with appropriate training (ibid.). However, provision of mentor education is not a requirement of ITE providers which partially explains why mentor education for ITE is currently not available (Education Scotland 2015). It is only accessible to a small minority of mentors who oversee post-ITE induction year teachers. The McCrone Agreement (Scottish Executive 2001), a review of teachers' pay and conditions, sees teachers as not required to mentor student teachers or newly qualified teachers (Kirk 2000). Mentoring is viewed as a professional obligation, expected from external organisations, a matter of dedication and personal desire (Brisard, Menter and Smith 2006). The most recent review does 
not formalise this requirement but it does recognise the importance of mentors within the induction year (McCormac 2011). These are salient factors given the complexity of the mentoring process (Hall, 2003) and the multiple, potentially conflicting roles often required of mentors such as being both mentor and assessor (Fransson 2010). Research evidence reports positive correlations between mentor education and the quality of subsequent mentoring practices (for example, Harrison et al. 2005; Crasborn, Hennison, Brouwer, Korthagen and Bergen 2011; Hoffman, Wetzel, Maloch, Greeter, Taylor, DeJulio and Khan Vlach 2015).

\section{Methodology}

A constructivist methodological approach was undertaken in the study. Constructivism has been defined variously (Larochelle, Bedwarz and Garrison 1998) but in educational contexts two conceptions are commonly deployed, namely cognitive constructivism, with its emphasis on the individual's construction of knowledge, and social constructivism where knowledge is constructed through interaction with others (Phillips 2000). Case study promotes thorough exploration of social phenomena in that different viewpoints of participants can be depicted and investigated comprehensively (Simons, 2009), including elucidation of possible reasoning behind particular findings rather than just the findings themselves (Denscombe, 1998). As such, it is an apposite design for constructivist research which is exploratory and process-oriented promoting in-depth studies of complex social phenomena focused on understanding significant elements of real-world contexts (Merriam 1998; Yin 2003; Jonassen 2006). This study's focus on mentor teacher and student teacher understandings of mentoring within a school placement context concerns lived experiences of the mentoring process, including the influence of contextual factors (school, local, national, beliefs and values) through analysis of mentor and mentee understandings.

A qualitative instrumental, collective case study and associated methods was employed. It is 'instrumental' by examining an overarching case, the process of mentoring primary student teachers, and is used to comprehend a phenomenon: mentor and mentee understandings of mentoring. It is 'collective' to provide a more holistic view of that phenomenon (Stake 2005) where individual cases are examined but situated within a collective study. Within the overarching collective case of the mentoring process four individual cases were investigated: class teacher mentors, student teachers (mentees), school management mentors and local authority mentors. Six student teachers and their class teacher mentors were recruited resulting in six mentoring pairs. This structure enabled comparative analysis where appropriate. A purposeful sampling strategy was employed in selecting student teachers at a particular stage on their undergraduate primary education degree. The rationale is that students in year three have experience of the mentoring process from a previous placement and would be able to use the experiences gained through this study to build on and enhance professional learning, and to draw on this learning in their final year four placement. Class teacher mentors were all qualified primary class teachers ranging in age and experience from those at the beginning of their career to others at a variety of stages, from mid-career to nearing retirement. Two of the six were promoted members of staff. Three of the six were experiencing being a mentor for the first time. The other three had mentored many students in the course of their teaching careers.

Key aspects of research ethics relevant to this study are informed consent, confidentiality, accuracy of reporting and positionality. The student teachers 
interviewed were from the researcher's own university programme thus cognisance of possible issues was important such as the 'interviewer effect' where interviewees say what they think interviewers want as opposed to giving an honest response (Denscombe 1998). To circumvent such issues, mentees were informed that the researcher's role in this school placement was as a doctoral student rather a university tutor. Resultantly, students came across as open in their responses. This may have been assisted by the researcher's own attitudes and beliefs about the significance of building positive relationships with students as they were comfortable and therefore confident to give honest responses. This was apparent through their relaxed nonverbal body language and suggested through laughter and shared amusing stories. Honesty in responses was evident, for example, in their willingness to criticise mentors and share their thoughts about potential improvements to school placement experiences. Further, a strategy of 'detached honesty' was adopted through critically questioning and challenging the research undertaken (Gillham 2000). For example, colleagues were an important source of advice about the research process and data analysis. They were also helpful in examining the reasonableness of findings and ensuing interpretations when coding data and synthesising those codes to abstract key themes. A critical, analytical approach to findings was adopted, recognising opportunities for numerous interpretations through the reading of literature and communications with participants. Given the qualitative nature of this study, traditional positivist notions of generalisation are viewed as inappropriate. The notion of a 'fuzzy' generalisation may be apposite in that no absolute social truths are claimed, just potentialities for research findings to be more widely applicable in terms of influencing policy and practice through dialogue between relevant parties (Bassey 1999).

To foster methodological congruence, data collection, analysis and interpretation are viewed as active (Esterberg 2002) and shared with participants as co-creators of data and meaning. Given the instrumental, collective case study design of this study, semi-structured interviews were most appropriate in explicating data specific to each case as well as fostering comparative analysis of data sets (ibid.). Interview schedules were formulated around the research focus with associated themes from the literature review noted alongside. To explore their understandings participants were asked a variety of questions about mentoring with regard to whom it involved, its forms, benefits, and the roles, characteristics and styles of mentors and mentees. A probing strategy was employed as the flexibility of the semi-structured interview allows for comprehension of viewpoints of participants' lived world (Kvale 2007) during the interview and so presents opportunities for the interviewer to probe further thereby fostering analytical depth (May 2001). The first interview aimed to ascertain individually constructed understandings of the mentoring process based on prior experiences of mentoring/being mentored. The second interview was used to uncover understandings of the mentoring process within the current mentoring experience. The interest here was not only in the 'in situ' understandings themselves, but also in whether they were different from those expressed previously. This was to identify dominant understandings that could be attributed to being within this particular mentoring relationship as opposed to those constructed/co-constructed from prior experiences. To maintain confidentiality of participants each was assigned a pseudonym, for example, class teacher mentor A - CTA, student teacher A - STA.

Constructivist grounded theory was used as an approach to data analysis and theory generation as this provided systematic guidelines for analysis where theories are constructed from the data gathered (Charmaz 2006). The classic notion of a 
'silent' researcher objectively 'discovering' data based on established theory is replaced by a researcher as author in rebuilding participants' understandings (Hallberg 2006). Use of research memos and consistent notation of emerging themes, absences and interesting elements for each research question enabled abstraction of meaning from data at a more holistic level while also engaging with the finer detail through coding. Three stages of coding were adopted: initial, focused and theoretical (Charmaz 2006) within and across cases, resulting in themes and sub-themes being identified. Analysis for commonality, whilst noting salient differences, was determined to be an effective basis for justifying construction of theoretical coding/themes. To exemplify the coding process: initial (line-by-line) codes from CT mentors about the role of the mentor within mentoring conversations included 'giving information about how to deal with a situation', 'giving pointers', 'giving advice', and 'giving suggestions'. These terms were synthesised into a focused code of 'giving advice'. Amalgamated with like focused codes, it contributed to the professional dimension of mentoring being coded as a sub-theme. Cross-case analysis of emergent themes and sub-themes was then carried out to further refine them.

\section{Findings and Discussion}

Analysis of data revealed that participants understood mentoring as a multidimensional process involving a range of relationships designed to support the mentoring of student teachers within a school placement context. Responses indicate that the key relationship is that between CT mentor and mentee essential in developing mentee teaching capacity. It is a close one, evident on a daily basis within the classroom and broader expectations derived from degree stage and GTCS competency expectations. CT mentor and mentee responses suggest a sub-theme of personal and professional dimensions. From these dimensions further sub-themes of collaboration and power emerge. This article focuses on the initial findings of personal and professional dimensions of mentoring. Themes and sub-themes are illustrated in Figure 1.1.

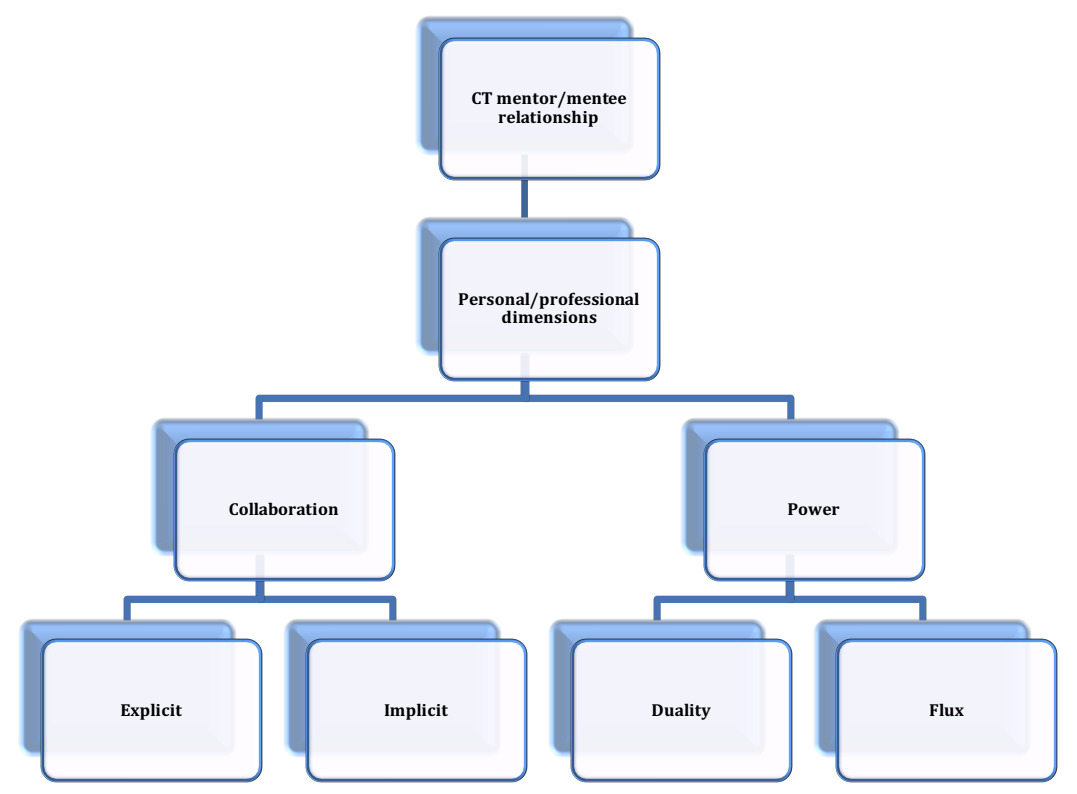

Figure 1.1: Class Teacher Mentor/Mentee Relationship. 
Yeomans and Sampson's (1994) theory of mentoring work was employed as an analytical framework as it facilitates exploration of complete mentoring relationships as opposed to individual component parts. It encompasses three elements: structural, supportive and professional (ibid.). The supportive element is re-named as 'personal' because participants in this study used the term 'support' in respect of professional aspects of teaching as well as referring to personal/pastoral care dimensions. This label is apposite given that this dimension involves mentor roles such as being a friend and/or counsellor who exhibits interpersonal skills like empathy and encouragement.

\section{Personal and professional dimensions as connected}

Recognition of the personal dimension of mentoring was limited and narrow within and across cases in that responses were primarily focused on professional elements. Within and cross-case data is summarised in Table 1.1 and a selection of examples subsequently presented.

Table 1.1: Personal Dimension.

\begin{tabular}{|c|c|c|}
\hline & Class teacher mentors & Mentees \\
\hline \multicolumn{3}{|l|}{$\begin{array}{l}\text { Forms taken by } \\
\text { mentoring process }\end{array}$} \\
\hline Mentoring style & having friendship & having friendship \\
\hline Mentor role & & reassuring \\
\hline Mentee role & $\begin{array}{l}\text { being enthusiastic } \\
\text { empathy: recognising that } \\
\text { everyone makes mistakes }\end{array}$ & \\
\hline \multicolumn{3}{|l|}{$\begin{array}{l}\text { Mentor role in mentoring } \\
\text { conversations }\end{array}$} \\
\hline \multicolumn{3}{|l|}{$\begin{array}{l}\text { Mentee role in mentoring } \\
\text { conversations }\end{array}$} \\
\hline $\begin{array}{l}\text { Characteristics of } \\
\text { effective mentor }\end{array}$ & $\begin{array}{l}\text { reassuring } \\
\text { empathy: recognising all } \\
\text { make mistakes }\end{array}$ & $\begin{array}{l}\text { being approachable } \\
\text { empathy: recognising all } \\
\text { make mistakes }\end{array}$ \\
\hline $\begin{array}{l}\text { Characteristics of } \\
\text { effective mentee }\end{array}$ & $\begin{array}{l}\text { being open to constructive } \\
\text { criticism }\end{array}$ & $\begin{array}{l}\text { being open to constructive } \\
\text { criticism }\end{array}$ \\
\hline $\begin{array}{l}\text { Characteristics of } \\
\text { effective mentoring } \\
\text { relationship }\end{array}$ & $\begin{array}{l}\text { being personal trust } \\
\text { getting on }\end{array}$ & $\begin{array}{l}\text { being personal trust } \\
\text { getting on } \\
\text { being supportive (care; } \\
\text { value; being appreciated) }\end{array}$ \\
\hline \multicolumn{3}{|l|}{$\begin{array}{l}\text { Benefits of mentoring for } \\
\text { the mentor }\end{array}$} \\
\hline $\begin{array}{l}\text { Benefits of mentoring for } \\
\text { the mentee }\end{array}$ & & \\
\hline
\end{tabular}

*Cross-case commonalities

Neither CT mentors nor mentees recognised any personal dimension of mentoring with regard to mentor and mentee roles in mentoring conversations, or in terms of benefits of the mentoring process for mentors or mentees. Within case data evidences differences in perspective about mentor and mentee roles. CT mentors viewed being 
enthusiastic and empathetic as significant mentee roles whereas mentees viewed their role as focused on the professional dimension of learning to teach. Similarly, mentees saw reassurance as a role of the mentor whereas CT mentor responses were about professional aspects of mentoring.

CT mentors and mentees acknowledged a personal element in responses about mentoring style, what constituted an effective mentoring relationship, and the characteristics of an effective mentor and mentee. Rather than noted as significant in isolation, these elements were linked to the professional learning of mentees exemplifying a connection between personal and professional dimensions. This connection aligns with other studies (for example, Yau 1995; Kwan and Lopez-Real 2005; Jones 2009; Hargreaves 2010; Jaspers, Meijer, Prins and Wubbels 2014). With regard to mentoring style, CTB suggested that there should be friendship in the relationship. This element was also evident in the response of STB linked to making it easier to approach the CT mentor about issues and ask questions. CTB further indicated that putting the mentee at ease was important.

I think you have to develop.... a sort of friendship...And especially... with (participant name)...I think that it's important to try to make her feel... at ease. So there has to be a wee bit of a personal rapport between you. CTB

I think there has to be an element of friendship. You're in somebody's classroom...you're working alongside them daily... at the end of the first day, she was...'so how was it'?...I said, 'I'm absolutely shattered'! And... she just came over and gave me a hug...that's important to me... it makes her more approachable...you could express your concerns... it makes it a lot easier if we have to go up and speak and ask things. STB

As regards getting along, CT mentors as approachable and positive was noted as significant as well as mentees being willing to engage in the process of learning to teach. CTB felt that the mentee being happy and learning assisted in them having a good relationship. STD also noted this connection in her reflection that having a good friendship based on talking about more than just classroom practice helped the relationship to become an 'honest' one where she felt more able and comfortable to ask the CT mentor for help. This kind of amiable communication facilitates discussion of professional elements especially regarding areas of difficulty identified in the mentee's teaching practice (Yeomans and Sampson 1994).

Responses about effective mentor characteristics evidence empathy, specifically recognition that everyone makes mistakes, as a key aspect. CTC suggested that reassurance is important as all teachers make errors, not just student teachers. STC expressed the view that this acknowledgement of the fallibility of all teachers would be something she would expect of her mentor.

I think you have to reassure them that everybody gets it wrong. Certainly I've already told (participant name) that there are days where sometimes I think 'oh that didn't go very well, I'll not do that again'. And that's something that you have to get used to as a teacher... sharing...bad experiences with them makes them feel better cause they realise 'oh right I' $m$ not the only person who gets it wrong'. CTC I would expect them to say 'do you know what, these days happen and it happens to us all. But you're a professional. It's what you're paid to do'. STC

In this respect, empathy, meaning being openly receptive to attempting to feel, experience and respond cordially to the descriptions of another person's experiences 
(Pask and Joy 2007), may be seen as facilitating professional dialogue. This is especially important if there are issues with the student teacher's teaching practice (Yeomans and Sampson, 1994). However, identification with such feelings can be challenging for a mentor in terms of controlling their own emotions (Pask and Joy 2007) in order to respond appropriately, professionally and constructively.

Personal trust was seen as building up over time and facilitated by getting to know each other, which, in turn, fostered the development of positive, open communication. CTA felt that becoming more closely acquainted had helped form a bond of trust. STB noted trust in terms of feeling that the mentor was communicating openly rather than mocking her covertly. Related to personal trust, professional trust was understood as a key aspect with regard to characteristics of an effective mentoring relationship. CT mentors noted that mutual trust was built up over time and talked specifically about the importance of trusting the mentee with confidential information as well as the mentee trusting the advice of the mentor. This was also the case with mentees who maintained that trusting the advice and experience of mentors was significant as well as being trusted to be working within the class and with teaching resources. CTA, CTD and STD described trusting the mentee with confidential information about the class. CTD also talked about the mentee trusting in the advice offered, and being trusted to be left on her own in charge of the learning and class management of the class. STD noted being trusted to be in the class and having mutual trust with regard to each other's resources. This kind of relationship, based on personal and professional trust, is significant because it fosters an ethos where professional as well as personal concerns can be discussed (Yeomans and Sampson 1994) and because, in the absence of a relationship based on personal trust, beginner teachers may be reticent to ask more experienced teachers for help for fear of being viewed as incompetent (Fransson 2010).

Indicative of mentoring complexity, the link between personal and professional dimensions may both help and hinder the mentoring process. An effective personal relationship facilitates a collaborative aspect of mentoring (Kwan and Lopez-Real 2005). This is key in developing active trust, which can be both personal and professional (Hargreaves 1994), and is actively pursued as opposed to resulting from expectations based on traditional hierarchies (Giddens 1994). Within collaborative practices the personal dimension is salient in fostering this learning, for example, in building mentee confidence and identity as teachers through encouraging them to experiment and take risks (Rajuan, Beijaard and Verloop 2007; Ambrosetti 2010). Laker, Laker and Lea (2008) also report that mentees placed greater value on feedback within personally supportive mentoring relationships. Such collaborative processes are underpinned by social constructivism where parties construct understanding through dialogue with others about the practicalities of learning to teach. In contrast, mentoring within a quality assurance focused environment may lead to a restricted view of it as supervision focused on skills (Rix and Gold 2000). This approach to mentoring does not promote dialogue as it is founded on accepted traditions and separation of groups (Sachs 2000) and potentially leads to relationships where dualities of power are evident such as expert and novice teachers, and is reported as unlikely to foster consistent professional or personal mentoring support (Jones 2009). However, a personal dimension may hinder a mentoring relationship by constraining professional dialogue. The sort of friendship in a mentoring relationship evident in this study may not be conducive to mentee professional learning in that it can be difficult for mentors to engage in discussions about development points for fear of offending the mentee (Kwan and Lopez-Real 2005). In this respect it is 
important to maintain professional distance (Yeomans and Sampson 1994), however, this is problematic in terms of how a mentor balances this distance with personal aspects of the relationship. An informed knowledge and understanding of the complexities of mentoring with regard to relationships and roles is required to facilitate this balance.

\section{Professional dimension}

Analysis of CT mentor and mentee data suggests that they comprehend mentoring as focused on the professional dimension which emphasises mentee development in learning to teach. Within and cross-case data evidences a focus on this dimension in responses about forms taken by the mentoring process, mentoring style, mentor and mentee roles, mentor and mentee roles within mentoring conversations, characteristics of effective mentors and mentees, and of an effective mentoring relationship. No difference in the nature of responses was evident between interviews one and two when questions were repeated about mentor and mentee roles within mentoring conversations and characteristics of an effective mentoring relationship. However, the extent of responses was more specific in places in interview two as participants were able to use the current mentoring experience to exemplify. This lack of 'in situ' difference suggests that, within the context of the existing placement context, participants were assimilating understandings constructed and co-constructed through previous experiences. Within and cross-case data is summarised in Table 1.2 and a selection of examples subsequently presented.

Table 1.2: Professional Dimension.

\begin{tabular}{|c|c|c|}
\hline & Class teacher mentors & Mentees \\
\hline $\begin{array}{l}\text { Forms taken by } \\
\text { mentoring process }\end{array}$ & $\begin{array}{l}\text { observing/being observed } \\
\text { giving feedback on next } \\
\text { steps }\end{array}$ & $\begin{array}{l}\text { observing } \\
\text { getting advice/feedback }\end{array}$ \\
\hline Mentoring style & $\begin{array}{l}\text { having a balance of } \\
\text { directive and non-directive } \\
\text { dialogue }\end{array}$ & $\begin{array}{l}\text { having a balance of } \\
\text { directive and non-directive } \\
\text { dialogue }\end{array}$ \\
\hline Mentor role & $\begin{array}{l}\text { giving feedback } \\
\text { giving ideas } \\
\text { observing formally and } \\
\text { informally } \\
\text { modelling } \\
\text { discussing the lesson }\end{array}$ & $\begin{array}{l}\text { sharing ideas } \\
\text { giving constructive } \\
\text { feedback } \\
\text { observing/being observed } \\
\text { building confidence } \\
\text { being positive } \\
\text { guiding } \\
\text { questioning re: self- } \\
\text { evaluation }\end{array}$ \\
\hline Mentee role & $\begin{array}{l}\text { learning } \\
\text { being open to constructive } \\
\text { dialogue } \\
\text { meeting university } \\
\text { expectations }\end{array}$ & $\begin{array}{l}\text { learning } \\
\text { observing } \\
\text { knowing areas that need } \\
\text { work }\end{array}$ \\
\hline $\begin{array}{l}\text { Mentor role in mentoring } \\
\text { conversations }\end{array}$ & $\begin{array}{l}\text { encouraging self- } \\
\text { evaluation } \\
\text { listening in order to } \\
\text { respond } \\
\text { guiding }\end{array}$ & $\begin{array}{l}\text { encouraging self- } \\
\text { evaluation } \\
\text { listening in order to } \\
\text { respond } \\
\text { guiding }\end{array}$ \\
\hline
\end{tabular}




\begin{tabular}{|c|c|c|}
\hline & $\begin{array}{l}\text { giving advice/feedback } \\
\text { encouraging the student to } \\
\text { lead conversations } \\
\text { leading } \\
\text { supporting positively } \\
\text { (strengths and } \\
\text { development points) }\end{array}$ & $\begin{array}{l}\text { giving feedback } \\
\text { encouraging student to } \\
\text { think } \\
\text { asking questions } \\
\text { avoiding telling answers }\end{array}$ \\
\hline $\begin{array}{l}\text { Mentee role in mentoring } \\
\text { conversations }\end{array}$ & $\begin{array}{l}\text { asking questions } \\
\text { feeling need to be } \\
\text { compliant } \\
\text { trying new things } \\
\text { self-evaluating }\end{array}$ & $\begin{array}{l}\text { asking questions } \\
\text { feeling need to be } \\
\text { compliant } \\
\text { recognising both have } \\
\text { input into conversations } \\
\text { feeling unable to disagree } \\
\text { taking advice }\end{array}$ \\
\hline $\begin{array}{l}\text { Characteristics of } \\
\text { effective mentor }\end{array}$ & $\begin{array}{l}\text { having practical } \\
\text { knowledge } \\
\text { being organised } \\
\text { being flexible } \\
\text { giving advice/feedback }\end{array}$ & $\begin{array}{l}\text { having practical } \\
\text { knowledge } \\
\text { being knowledgeable re: } \\
\text { university documents/input } \\
\text { being constructive }\end{array}$ \\
\hline $\begin{array}{l}\text { Characteristics of } \\
\text { effective mentee }\end{array}$ & $\begin{array}{l}\text { being open to constructive } \\
\text { criticism } \\
\text { learning } \\
\text { self-evaluating } \\
\text { communicating with } \\
\text { mentor and others } \\
\text { being involved with wider } \\
\text { school } \\
\text { taking forward } \\
\text { constructive feedback }\end{array}$ & $\begin{array}{l}\text { being open to constructive } \\
\text { criticism } \\
\text { learning } \\
\text { being able to self-evaluate }\end{array}$ \\
\hline $\begin{array}{l}\text { Characteristics of } \\
\text { effective mentoring } \\
\text { relationship }\end{array}$ & $\begin{array}{l}\text { being professional trust } \\
\text { communicating } \\
\text { having mutual respect } \\
\text { spending time }\end{array}$ & $\begin{array}{l}\text { being professional trust } \\
\text { having enough time }\end{array}$ \\
\hline $\begin{array}{l}\text { Benefits of mentoring for } \\
\text { the mentor }\end{array}$ & learning from the student & learning from the student \\
\hline $\begin{array}{l}\text { Benefits of mentoring for } \\
\text { the mentee }\end{array}$ & $\begin{array}{l}\text { asking questions/for help } \\
\text { being part of an } \\
\text { organisation }\end{array}$ & asking questions/for help \\
\hline
\end{tabular}

*Cross-case commonalities

Both CT mentors and mentees recognised learning as a key element of the role of the mentee. CT mentors placed importance on mentees being keen and committed to learn a variety of aspects about classroom practice. CTE noted learning about a variety of teaching practices and about working collegiately in particular.

To join in collegiate sessions and actually learn what it is like in a school...To look at the different ways classrooms can be organised as well. To look at how teachers cope with mixed abilities...And learning all a' those practical things that actually make a working classroom work effectively. CTE 
Mentees' focus was on learning as much as possible during their placement. STA placed particular importance on being seen to be willing to learn in her role as a student teacher. STC talked in more specific terms about the role of the student as a proactive one making effective use of the mentor to foster development of teaching practices.

I think you can't just go in and think that you're going to be told how to do everything and gonnae be spoon-fed...I think it's up to you as the mentee to go in and use your mentor effectively to allow your skills to develop... That's what you're there to do, we're beginners. You know, we're just learning. STC

Mentors giving feedback was understood as a key element in mentoring process. CT mentors talked about discussing strengths and development points with the mentee then giving feedback on next steps for teaching in future lessons. Mentees noted getting feedback on lesson content and pedagogy. Having consistent access to their CT mentors was also viewed as important. STB described the CT mentor as observing lessons and giving constructive feedback on positive aspects as well as areas to work on.

...she would observe and she would give constructive feedback. And...she...pointed me in the right direction. She told me what was good. She said areas to work on which I thought was... really good. STB

Providing feedback was also understood as part of the mentor's role. A focus on strengths as well as areas for development was again noted. STC maintained that feedback was a main component in how mentors can support mentees through giving positive points and aspects for development. She felt some were afraid to highlight areas for improvement but stressed that mentees needed that feedback in order to progress. CTF used a formative assessment technique (stars and wishes) after lessons to balance feedback given and to regulate the amount for mentees to think about. Ideally, feeding back took place right away in order that mentees did not over focus on negative aspects.

I tend to do two stars and a wish for individual lessons. They cannot improve everything right away...It is a long slow process...I try to meet immediately after they have done a direct teach, so that we can get immediate feedback because once you have had time to self-reflect on it you tend to think 'I didnae do that. I could have done that better'. CTF

Within mentoring conversations, giving feedback was described by CT mentors as balanced towards ways to improve rather than positive aspects. CTA saw one of her roles as giving information based on her own experiences about how to address certain aspects so the mentee could use it in her own practice. CTE felt that it was also important to listen to the mentee's views, however, if she considered what the mentee was suggesting to be inappropriate, she would direct her towards a different approach based on her own teaching experiences. She further noted that the mentee should not take this personally. STE stated that she received a lot of feedback, mainly verbal but written when required, and that her CT mentor did focus on strengths as well as development points to help her remain realistic in terms of expectations of herself. 
One characteristic of an effective mentee was noted as being able to engage in self-evaluation about teaching episodes. Mentees talked about the need to evaluate their practice in terms of what went well and what required attention. CT mentors also noted this aspect and further viewed it as significant in terms of fostering professional learning. CTE highlighted the importance of considering reasons behind certain outcomes and of thinking about next steps in their teaching practice.

I think if they can actually really focus on their own practice and actually say, pick out why something didn't go well...evaluate themselves, see if they can come up with a way forward. CTE

Symptomatic of the complex nature of mentoring, the professional dimension may involve mentors adopting roles such as trainer, educator and assessor (Yeomans and Sampson 1994). Trainer and educator roles are predominantly evident in this study as no explicit understanding of a mentor as assessor was expressed, however, implicit awareness is apparent, for example, through CT mentors being viewed as having roles of giving feedback and observing. The lack of explicit recognition of mentor as assessor may be explained in that this role in Scottish schools is assumed, established practice. Jones and Straker (2006) suggest that such an assumption may be due to the influence of a teacher education competency framework used for target setting, quality assurance and accountability purposes.

A training role entails mentors acting in ways that aim to assist mentees to deal efficiently with specific teaching situations (Yeomans and Sampson, 1994). In this respect, more directive strategies such as demonstrating/modelling, commentating, advising and telling are employed (ibid.). To exemplify, mentoring strategies of advising and telling are evident in the data through CT mentors' role of giving feedback with regard to the content and pedagogy of mentees' teaching practice in order to foster professional learning. This feedback varied in its form, from CT mentors adopting an advisory role in listening to mentee views, being open to new techniques through providing opinions and deciding on the appropriateness of suggestions, to a more directive form of telling where the CT mentor would direct the mentee towards a tried and tested approach based on personal teaching experiences. An advisory strategy entails encouraging mentees to decide for themselves about their next steps in that it provides them with a starting point, for example, where they might look for the information required (ibid.). In this respect, it may be viewed as less than telling but not completely non-directive. In Yeomans and Sampson's (1994) study some mentors found this strategy challenging. In contrast, CT mentors in this project adopted advisory strategies by both giving direct feedback and being receptive to mentees having their own opinions, however, if what the mentee was suggesting was considered to be inappropriate, a more directive approach was employed.

The notion of mentors as trainers is indicative of a traditional instructionalbased, supervisory notion of mentoring (O'Brien and Christie 2005), based on a power duality, where mentors are narrowly conceptualised as experts tasked with transmission of knowledge and mentees as novice receptors of such knowledge. Aims are based around competency standards, such as those in the SITE (GTCS 2012), to foster capable and independent teachers (Kemmis et al. 2014). This training/supervisory approach to mentoring is likely to foster relationships where mentors advise, dominate talk, view themselves as the expert and are product rather than process focused (Carnell et al. 2006). These strategies are common in schools 
and higher education. They are akin to an instructional model of learning and widely recognised as not conducive to effective learning or mentoring (Rogers 2004).

As such, they may be suggested as inadequate given the demands of a knowledge society and existant educational reforms. However, it is important to acknowledge that, from a developmental perspective, appropriate support should be provided for mentees as they progress through the stages of learning to teach (Pollard 2005). This perspective maintains that in the early part of teacher professional learning mentors may need to adopt a more directive approach ( $\mathrm{ibid}$.). There are also instances within mentoring relationships when direction in the form of telling is apposite, for example, in giving requisite information on pupil pastoral and academic concerns, and with regard to health and safety issues (Hargreaves 2010).

Within the professional dimension a mentor may also adopt the role of an educator (Yeomans and Sampson 1994). This entails mentors assisting mentees to move further from current practice-specific situations to analysis and application in other contexts (ibid.). In this respect, strategies such as discussing, reflecting, questioning and facilitating are employed (ibid.). This study's findings indicate that the ability to carry out self-evaluation of teaching practices was understood as a key characteristic of an effective mentee. This took the form of mentees reflecting on their practice in terms of thinking about strengths and development areas as well as specifying next steps in teaching. Schön (1987) describes reflection-in-action as that which occurs while teaching and reflection-on-action as reflection in retrospect, used for analytical purposes to foster understanding. He maintains that these are necessary in learning to teach (ibid.) Reflection-on-action was evident from mentees in this study and is, arguably, more valuable for mentors and mentees as it involves both deconstructing and reconstructing teaching, and fosters the capacity in mentees to apply new knowledge and understanding to different situations therefore fostering change in practices (Yeomans and Sampsons 1994). Mentees' consideration of their next steps in teaching is indicative of reflection-for-action where beginner teachers make sense of their learning to increase understanding (Harrison et al. 2005) making progress in professional learning more likely. The kind of reflection on strengths and development points mentees engaged in could be interpreted as a simplified notion of just talking about the events of a lesson (Bleach 1997). However, it is argued that reflection needs to be explored in a meaningful way in order to promote professional learning ( $i b i d$.). Findings indicate that this is evident in the form of mentee consideration of reasons behind lesson outcomes in terms of why some aspects of the lesson had been successful and others not. This type of reflection is concerned with asking questions about current beliefs and practice based on personal experiences of schooling and teacher education (Harrison et al. 2005; Graham 1999). Its aim is to promote positive change in teaching practices through engagement in metacognitive thinking and individuals taking responsibility for their own learning. CT mentors in this study encouraged mentees to engage in such reflection and so were adopting an educative role, facilitating more in-depth, insightful consideration (Schwille 2008).

Mentors' adoption of an educative role is indicative of a conceptualisation of mentoring as active, self-regulated learning (ibid.). The focus of this mentoring is not just on learning about current practice but on the transference of knowledge to different situations (Rajuan et al. 2007). This approach appears more adequate given the demands of a knowledge society where a variety of teacher characteristics are desirable. Mentors adopt a collaborative approach with mentees (Feiman-Nemser and Parker 1992) to promote professional learning through encouraging them to employ a questioning approach, and by assisting them to overcome issues as opposed to simply 
directing them to solutions (Iancu and Oplatka 2014). Educative mentoring entails mentors employing their knowledge of teaching and learning to decide on the most appropriate ways to support mentee professional learning (ibid.). This role again aligns with constructivism with regard to mentees actively constructing understanding by amending existing schemata through processes of assimilation and accommodation (Bredo 2000) based around reflection on their teaching experiences. Mentors also adopt a scaffolding role within mentees' 'zones of proximal development' in order to assist them in developing more advanced knowledge, understanding and skills.

In discussing trainer and educator roles of mentors, the complex nature of mentoring is again apparent. These roles may overlap depending on the mentoring context and/or aims (Yeomans and Sampson 1994). In this study an overlap is evident regarding feedback where CT mentors advise through both offering direct advice and encouraging mentees to think for themselves. Appropriate mentoring approaches should be enacted when and where required in terms of mentee need (Pollard 2005). It may be argued that training is more evident when mentees are at the beginning of their learning therefore can be categorised more as novice teachers and so focused on understanding basic teaching principles. An educative approach may be more appropriate progressively allowing more focus on development of mentee independence in decision-making. However, learning to teach is not a linear process (Furlong et al. 2000) thus it could be suggested that an educative approach may be adopted from the outset in accordance with constructivist theories on learning. In reality, mentoring comprises different approaches, however, theoretically each is aligned with particular perspectives on teaching, which conflict and may cause confusion (Kemmis et al. 2014). In this respect, an informed knowledge and understanding about mentoring, including clarity regarding mentoring aims and participant roles, is vital to foster effective mentoring where the focus is on mentee professional learning.

Further indicative of mentoring complexity, CT mentors and mentees' focus on the professional dimension of mentoring may be explained in a variety of ways. For example, conceptions of mentoring as a developmental process so that appropriate support is provided for mentees may be considered (Pollard 2005). In the early part of teacher development, such as the student teachers in this study who were in their second five-week school placement, mentees may need a more directive approach. As mentees move through the stages mentors use and adjust mentoring strategies to ensure they are appropriate. Professional support may decrease and therefore lead to a greater focus on personal aspects (Rippon and Martin 2003; Certo 2005; Jones 2009). Since mentees in this study were early on in their ITE school placement experiences, it seems legitimate that CT mentors' prioritised professional over personal dimensions of the mentoring relationship. However, it could be argued that this was fostered by their sole dependence on experiential knowledge and understanding of mentoring, as opposed to specific awareness and a more informed understanding of these two dimensions that may be promoted by formal mentor education opportunities.

Additional considerations in explaining the focus on professional elements are of internal and external pressures regarding quality assurance and accountability. In this respect school pupil and mentee learning are relevant given that both are influential in the mentoring of student teachers. In the current Scottish education context pupil learning is the main focus due to quality frameworks of accountability such as HGIOS (How Good is our School?), parental expectations, unofficial league tables, HMIe (Her Majesty's Inspectorate of Education) inspections and subsequent 
published reports. Schools are subject to inspection procedures by HMIe. These inspections focus on educational quality and standards with the aim of promoting improved and innovative practices to foster better learning experiences for pupils. Quality indicators such as HGIOS 2 are employed by HMIe inspectors to support appraisals and inform comments on ways schools might make improvements. Due to competing demands, mentor support of mentees can be detrimentally affected due to a tension between responsibility for pupil learning and for that of the mentee (Rajuan et al. 2007). This may be exacerbated if mentoring takes place within the mentor's own class, as in this study, as mentors feeling of responsibility for pupil learning is heightened (Yeomans and Sampson 1994). The primary school context might also increase feelings of responsibility because teachers are in charge of one class of pupils as opposed to several as in secondary school settings (Jaspers et al. 2014). This dual responsibility can lead to mentors being conflicted in their approach and with regard to professional trust because as mentors they may want to encourage mentees to address complex situations and learn, however, as class teachers they are reticent to subject pupils to potentially detrimental learning experiences (ibid.).

Mentoring beginner teachers in Scotland is also influenced by external quality assurance and accountability. The GTCS professional competency standards could be argued as a factor in CT mentor and mentees' predominant focus on the professional dimension of their relationship. These are set and regulated by the GTCS, Scotland's independent, self-regulatory teaching council. Registration with this council is required in order to teach in Scotland. There are professional competency standards for all teachers irrespective of age, stage or context, and judgements are made by the GTCS on whether these are met on a career long continuing professional learning basis from ITE onwards. In this respect, as in this study, activities for completion within school placement guidelines provided by universities are based on these standards, which are also used to assess competency at the end of the placement. The influence of these standards pervades ITE in that it provides benchmarks for the design and assessment of professional learning programmes, inclusive of academic and school placement components.

\section{Conclusion}

This article addressed mentors' and student teachers' understandings of mentoring within Scottish ITE school placement contexts. It introduces a Scottish perspective to the international body of literature on student teacher mentoring, and furthers understandings by addressing the role of mentees as well as those of the mentor, thereby filling a gap in current literature (Ambrosetti 2010). Findings indicate that participants understood mentoring as a multidimensional process designed to support the professional learning of student teachers. Discussion of the data exhibits the complex nature of the mentoring process in terms of the multitude of potential interpretations of these two dimensions and of the ways in which they overlap. Resultant suggestions are that mentors require a more informed knowledge and understanding of mentoring and its inherent complexity to foster quality and consistency of mentee learning experiences. Ambrosetti (2014) notes that class teacher mentors of ITE students are generally not confident about mentoring, which can result in inappropriate support for mentee learning being provided. Likewise, in Scotland, variability in the quality of school placements is reported in the latest review of partnership between local authorities and university ITE providers (Education Scotland 2015). 
The findings of this study suggest that mentor education may help to improve the quality and consistency of mentoring for student teachers as it can promote more informed knowledge and understanding of the mentoring process. A further consideration is that the responsibility for these experiences does not just lie with mentors. The inclusion of mentees in mentor education opportunities is vital in order that they are informed and equipped to more effectively engage in the mentoring process. In Scotland any mentor education available is targeted at those involved in the post-ITE induction programme with mentors reporting positive effects of such input (Education Scotland 2015). Its importance is well documented in promoting quality and consistent mentoring experiences (for example, McCormack and Thomas 2003; Lopez-Real and Kwan 2005; Hobson, Ashby, Malderez and Tomlinson 2009; Pogodzinski 2012; Hudson 2013; Langdon 2014). However, it is reported as inconsistent in terms of its quality and availability (for example, Bubb, Earley and Totterdell 2006). Therefore, an important consideration for teacher educators programmes and associated placement schools is the provision of effective mentoring education programmes for all teachers to foster adequate support for student teachers as well as those in post-ITE contexts. 


\section{References}

Achinstein, B. and Davis, E., 2014. The Subject of Mentoring: Towards a Knowledge and Practice Base for Content-focused Mentoring of New Teachers. Mentoring and Tutoring: Partnership in Learning, 22 (2), 104-126.

Ambrosetti, A., 2012. Mentoring and Learning to Teach: What do Pre-service Teachers Expect to Learn from their Mentor Teachers? The International Journal of Learning, 17 (9), 117-132.

Ambrosetti, A. and Dekkers, J., 2010. The Interconnectedness of the Roles of Mentors and Mentees in Pre-service Teacher Education Mentoring Relationships. Australian Journal of Teacher Education, 35 (6), 42-55.

Ambrosetti, A. Knight, B.A. and Dekkers, J., 2014. Maximizing the Potential of

Mentoring: A Framework for Pre-service Teacher Education. Mentoring and

Tutoring: Partnership in Learning, 22 (3), 224-239.

Arnot, J. and Sparrow, J., 2004. The Coaching Study, 2004: Coaching works but it could get better. Birmingham: Origin and University of Central England.

Bleach, K.. 1997. The importance of critical self-reflection in mentoring newly qualified teachers. Mentoring and Tutoring, 4 (3), 19-24.

Bredo, E., 2000. 'Reconsidering social constructivism: The relevance of George Herbert Mead's interactionism'. In Phillips, D.C., (Ed.) Constructivism in Education: Opinions and Second Opinions on Controversial Issues. Illinois: The National Centre for the Study of Education.

Carnell, E., MacDonald, J. and Askew, S., 2006. Coaching and Mentoring in Higher Education: A learning-centred approach. London: Institute of Education.

Bassey, M., 1999. Case Study Research in Educational Settings. Berkshire: Open University Press.

Bubb, S., Earley, P. and Totterdell, M., 2005. Accountability and responsibility: 'rogue' school leaders and the induction of new teachers in England. Oxford Review of Education, 31 (2), 255-273.

Charmaz, K., 2006. Constructing Grounded Theory. London: Sage Publications Ltd.

Cordingley, P., Bell, M. and Temperley, J., 2005. Mentoring and Coaching for Learning. Professional Development Today, 8 (2), 15-19

Crasborn, F., Hennison, P., Brouwer, N., Korthagen, F. and Bergen, T., 2011. Exploring a two-dimensional model of mentor teacher roles in mentoring dialogues. Teaching and Teacher Education, 27, 320-331.

Cresswell, J.W., 2007. Qualitative Inquiry and Research Design. London: Sage Publications Ltd.

Deloitte and Touche., 2001. The Scottish Executive-Report of the 'First Stage' Review of Initial Teacher Education. Edinburgh: Deloitte and Touche.

Desimone L.M., Hochberg, E.D., Porter, A.C., Polikoff, M.S., Schwartz, R. and Johnson, L. J., 2014. Formal and Informal Mentoring: Complementary, Compensatory, or Consistent? Journal of Teacher Education, 65 (2), 88-110.

Education Scotland., 2015. Aspect Review of the Education Authority and University ITE Partnership Arrangements (phase one). Livingston: Education Scotland.

Dewhurst, Y. and McMurty, D., 2006. The effectiveness of school placements in facilitating student teacher learning and professional development. Scottish Educational Review, 38(2), 158-172.

Esterberg, K.G., 2002. Qualitative Methods in Social Research. London: McGrawHill Higher Education. 
Feiman-Nemser, S. and Parker, M.B., 1992. Mentoring in Context: A Comparison of Two U.S. Programs for Beginning Teachers. National Centre for Research on Teacher Learning Special Report, 1-17.

Forde, C., McMahon, M., McPhee, A.D. and Patrick, F., 2006. Professional Development, Reflection and Enquiry. London: Paul Chapman Publishing.

Fransson, G., 2010. Mentors assessing mentees? An overview and analyses of the mentorship role concerning newly qualified teachers. European Journal of Teacher Education, 33 (4), 375-390.

Furlong, J., Barton, L., Miles, S., Whiting, C. and Whitty, G., 2000. Teacher Education in Transition. Buckingham: Open University Press.

Gardiner, W., 2009 Rudderless as mentors: The challenge of teachers as mentors. Action in Teacher Education, 30(4), 56-66.

Giddens, A., 1994. Beyond Left and Right: The Future of Radical Politics. Oxford: Polity Press.

Grabinger, S., Dunlap, J.C., and Duffield, J. A., 1997. Rich environments for active learning in action: problem-based learning. ALT-J, 5 (2), 5-17.

Graham, P., 1999. Powerful influences: a case of one student teacher renegotiating his perceptions of power relations. Teaching and Teacher Education, 15, 523-540

GTCS., 2012 Teacher Journey:

http://www.gtcs.org.uk/TeacherJourney/teacher-journey.aspx [accessed: 15.2.16]

Hall, J.C., 2003. Mentoring and Young People: A literature review. York: Reports Press.

Hallberg, L.R-M., 2006. The 'core category' of grounded theory: Making constant comparisons. International Journal of health and Well-being, 1, 141-148.

Hargreaves, A., 1994. Changing Teachers, Changing Times. London: Cassell.

Hargreaves, E., 2010. Knowledge Construction and Personal Relationship: Insights About a UK University Mentoring and Coaching Service. Mentoring and Tutoring: Partnership in Learning, 18 (2), 107-120.

Hargreaves, A. and Fullan, M., 2000. Mentoring in the New Millennium. Theory into Practice, 39 (1), 50-56.

Harrison, K., Lawson, T. and Wortley, A., 2005. Mentoring the beginner teacher: developing professional autonomy through critical reflection on practice. Reflective Practice, 6(3), 419-441.

Heirdsfield, A. M., Walker, S., Walsh, K. and Wilss, L., 2008. Peer mentoring for first-year teacher education students: the mentors' experience. Mentoring and Tutoring: Partnership in Learning, 16 (2), 109-124.

Hennison, P., Crasborn, F., Brouwer, N., Korthagen, F. and Bergen, T., 2008. Mapping mentor teachers' roles in mentoring dialogues. Educational Research Review, 3, 168-186.

HMIe., 2005. Student Teacher Placements within Initial Teacher Education. Livingston: HMIe.

Hobson, A.J., Ashby, P., Malderez, A. and Tomlinson, P.D., 2009. Mentoring beginning teachers: what we know and what we don't. Teaching and Teacher Education: An International Journal of Research and Studies, 25 (1), 207-216.

Hoffman, J. V., Wetzel, M.M., Maloch, B., Greeter, E., Taylor, L., DeJulio, S. and Khan Vlach, S., 2015. What can we learn from studying the coaching interactions between cooperating teachers and preservice teachers? A literature review. Teaching and Teacher Education, 52, 99-112.

Hudson, P., 2013. Mentoring as professional development: 'growth for both' mentor 
and mentee. Professional Development in Education, 39 (5), 771-783.

Iancu-Haddad, D. and Oplatka, I., 2014. Mentoring Novice Teachers: Motives, Process, and Outcomes from the Mentor's Point of View. The New Educator, 5, 45-65.

Jaspers, W. M., Meijer, P.C., Prins, F. and Wubbels, T., 2014. Mentor teachers: Their perceived possibilities and challenges as mentor and teacher. Teaching and Teacher Education, 44, 106-116.

Jones, M., 2009 Supporting the Supporters of Novice Teachers: an analysis of mentors' needs from twelve European countries presented from an English perspective. Research in Comparative and International Education, 4 (1), 4-21.

Jones, M. and Straker, K., 2006 What informs mentors' practice when working with trainees and newly qualified teachers? An investigation into mentors' professional knowledge base. Journal of Education for Teaching: International research and pedagogy, 32 (2), 165-184.

Kemmis, S., Heikinnen, H.L.T., Fransson, G. and Aspfors, J., 2014 Mentoring of new teachers as a contested practice: Supervision, support and collaborative selfdevelopment. Teaching and Teacher Education, 43, 154-164.

Kvale, S., 1996. Interviews: An introduction to qualitative research interviewing. London: Sage Publications Ltd.

Kwan, T. and Lopez-Real, F., 2005 Mentors' perceptions of their roles in mentoring student teachers. Asia-Pacific Journal of Teacher Education, 33 (3), 275-287.

Lopez-Real, F. and Kwan, T., 2005. Mentors' perceptions of their own professional development during mentoring. Journal of Education for Teaching, 31 (1), $15-24$.

Maynard, T. and Furlong, J., 1993. Learning to teach and models of mentoring in Kerry, T. and Mayes, A.S., (Eds) Issues in Mentoring. London: Routledge.

Laker, A., Laker, J. C. and Lea, S., 2008. Sources of support for pre-service teachers during school experiences. Mentoring and Tutoring: Partnership in Learning, $16(2), 125-140$.

Langdon, F. J., 2014 Evidence of mentor learning and development: an analysis of New Zealand mentor/mentee professional conversations. Professional Development in Education, 40 (1), 36-55.

Larochelle, M., Bedwarz, N. and Garrison, J., 1998. Constructivism and Education. Cambridge: Cambridge University Press.

Littledyke, M. and Huxford, L., 1998. Teaching the Primary Curriculum for Constructive Learning. London: David Fulton Publishers.

May, T., 2001. Social Research: Issues, methods and process. Buckingham: Open University Press.

McCormak, A. and Thomas, K., 2003. Is Survival Enough? Induction experiences of beginning teachers within a New South Wales context. Asia-Pacific Journal of Teacher Education, 31 (2), 125-138.

McNally, J., 2002. Developments in Teacher Induction in Scotland and Implications for the Role of Higher Education. Journal of Education for Teaching: International research and pedagogy, 28 (2), 149-164.

O'Brien, J. and Christie, F., 2005. Characteristics of support for beginning teachers: evidence from the new Teacher Induction Scheme in Scotland. Mentoring and Tutoring: Partnership in Learning, 13 (2), 189-203.

Pask, R. and Joy, B., 2007. Mentoring-Coaching: a guide for education professionals. Berkshire: Open University Press. 
Pogodzinski, B., 2012. Considering the Social Context of Schools: A Framework for Investigating New Teacher Induction. Mentoring and Tutoring: Partnership in Learning, 20 (3), 325-342.

Pollard, A., 2005. Readings for Reflective Teaching. London: Continuum.

Rajuan, M., Beijaard, D., and Verloop, N., 2007. The role of the cooperating teacher: bridg- ing the gap between the expectations of cooperating teachers and student teachers. Mentoring and Tutoring: partnership in learning, 15 (3), 223-242.

Richter, D. Kunter, M., Lüdtke, O., Klusmann, U., Anders, Y., and Baumert, J., 2013. How different mentoring approaches affect beginning teachers' development in the first years of practice. Teaching and Teacher Education, 36, 166-177.

Rippon, J. and Martin, M., 2003. Supporting induction: relationships count. Mentoring and Tutoring. 11 (2), 212-225.

Rix, M. and Gold, J., 2000. 'With a little help from my academic friend': mentoring change agents. Mentoring and Tutoring, 8 (1), 47-62.

Rogers, J., 2004 Coaching Skills: A handbook. Milton Keynes: Open University Press.

Sachs, J., 2000. The Activist Professional. Journal of Educational Change, 1, 77-95.

Schön, D.A., 1987. Educating the Reflective Practitioner. London: Jossey-Bass Limited.

Schwille, S. A., 2008. The Professional Practice of Mentoring. American Journal of Education, 115, 139-167.

Scottish Executive., 2005. Stage 2 Review of Initial Teacher Education. Edinburgh: Scottish Executive.

Scottish Government., 2011. 'Teaching Scotland's Future'. Edinburgh: Scottish Government.

Stake, R.E., 2005. Qualitative Case Studies. In Denzin, N.K. and Lincoln, Y., (Eds) The Sage Handbook of Qualitative Research. London: Sage Publications Ltd.

Strong, M. and Baron, W., 2004. An analysis of mentoring conversations with beginning teachers: suggestions and responses. Teaching and Teacher Education, 20, 47-57.

UKK., 2014. Teacher Education In England: https://getintoteaching.education.gov.uk [accessed: 10.2.16]

Ulvik, M. and Sunde, E., 2013. The impact of mentor education: does mentor education matter? Professional Development in Education, 39 (5), 754-770.

Yau, C.K., 1995. From a student standpoint: 'My views on mentoring'. Mentoring and Tutoring, 3 (2), 45-49.

Yeomans, J. and Sampson, R., (Eds) 1994. Mentorship in the Primary School. London: The Falmer Press. 